\title{
Giant Sialocele Following Facial Trauma
}

\author{
Rui Medeiros JÚNIOR ${ }^{1,2}$ \\ Alípio Miguel da Rocha NETO2 \\ Isaac Vieira QUEIROZ ${ }^{1,2}$ \\ Antônio de Figueiredo CAUBY ${ }^{1}$ \\ Luiz Alcino Monteiro GUEIROS ${ }^{2}$ \\ Jair Carneiro LEÃO
}

\author{
${ }^{1}$ Oral and Maxillofacial Surgery Program, Hospital of Restoration, Recife, PE, Brazil \\ ${ }^{2}$ Oral Medicine Unit, Department of Clinics and Preventive Dentistry, UFPE - Federal University of Pernambuco, \\ Recife, PE, Brazil
}

\begin{abstract}
Injuries in the parotid and masseter region can cause serious impairment secondary to damage of important anatomical structures. Sialocele is observed as facial swelling associated with parotid duct rupture due to trauma. The aim of this paper is to report a case of a giant traumatic sialocele in the parotid gland, secondary to a knife lesion in a 40-year-old woman. Conservative measures could not promote clinical resolution and a surgical intervention for the placement of a vacuum drain was selected. Under local anesthesia, a small incision was performed adjacent to parotid duct papilla, followed by muscular divulsion and draining of significant amount of saliva. An active vacuum suction drain was placed for 15 days, aiming to form a new salivary duct. This technique was shown to be a safe, effective and low-cost option, leading to complete resolution and no recurrence after 28 months of follow up.
\end{abstract}

Key Words: parotid gland, sialocele, face.

\section{INTRODUCTION}

Sialocele is characterized by the accumulation of extravasated saliva around the secreting tissues of a salivary gland without a defined epithelial lining, usually occurring in a parotid gland following an episode of trauma (1). Common causes of parotid injuries include penetrating wounds (sharp instruments), perforating wounds (firearms) and injuries secondary to surgical procedures (2). Adequate diagnosis relies on a throughout clinical interview together with proper physical and imaging exams in order to discard other lesions of a similar appearance.

Parotid diseases including sialolithiasis abscess, parotitis, aneurism, hematoma and neoplasm may progress with an increased volume in the gland region usually allowing little clinical distinction (3). In this clinical setting it seems important to perform a correct diagnosis and immediate treatment of traumatic injury to the parotid gland avoiding the formation of cutaneous fistulae or salivary duct cysts (4).
There are distinctive treatments for a sialocele and the choice should rely on the time elapsed since the injury and affected region of the gland. Thus, conservative approaches, including compresses associated or not to medication and successive puncture and aspiration can be switched to or the installation of local drains or even a partial or complete parotidectomy in the absence of adequate clinical response (3). This paper describes and discusses an uncommon case of giant sialocele in the face secondary to trauma caused by a sharp weapon and adequately managed with placement of an active vacuum suction drain.

\section{CASE REPORT}

A 40-year-old female Brazilian patient victim of physical aggression with a sharp weapon (sickle) presented with an extensive facial and cranioencephalic trauma. Extraoral examination in the emergence room revealed an extensive laceration in the left masseter region extending to the parotid gland (parenchyma

Correspondence: Prof. Dr. Luiz Alcino Gueiros, Disciplina de Estomatologia, Departamento de Clínica e Odontologia Preventiva, UFPE, Avenida Prof. Moraes Rego, 1235, 50670-901 Recife, PE, Brasil. Tel: +55-81-2126-8816. Fax:+55-81-2126-8817. e-mail: luiz.mgueiros@ufpe.br. 
and salivary duct) and facial nerve, together with a suspected fracture of the mandibular ramus on the same side. A computed tomography (CT) scan was requested and confirmed the presence of the fracture (Fig. 1). After complete clinical evaluation she was submitted to a surgical intervention under general anesthesia to perform mandibular reduction and fixation together with immediate parotid reconstruction. Salivary gland reconstruction was limited due to the considerable loss of glandular parenchima and rupture of capsule and duct in various segments.

Recovery was uneventfully until the tenth day following surgery, when it could be observed an increase volume in the operated region measuring approximately $9 \times 6 \mathrm{~cm}$. Fever or trismus were not present and no signs of fistula or inflammation were observed. Anyhow, the skin was distended and had a thin, friable appearance. Palpation revealed a floating lesion of a soft consistency and discreet mobility and intraoral inspection revealed intact mucosa without fistula, but no drainage of saliva by the left parotid duct was observed following gland massage. An aspiration was carried out and revealed a clear, thick liquid compatible with salivary secretion. The diagnostic hypothesis of traumatic parotid sialocele was considered and confirmed by a new CT scan (Fig. 2).

Successive aspirations and compresses were applied to the region for 5 days, with no change in clinical aspect. Once resolution was not achieved, an active vacuum suction drain was then installed by intraoral access under local anesthesia, aiming cannulate a new salivary duct (Fig. 3). The device was left in for 15 days, leading to complete regression of the lesion and formation of a new glandular duct. The patient has been in follow up for 28 months, with no further complication

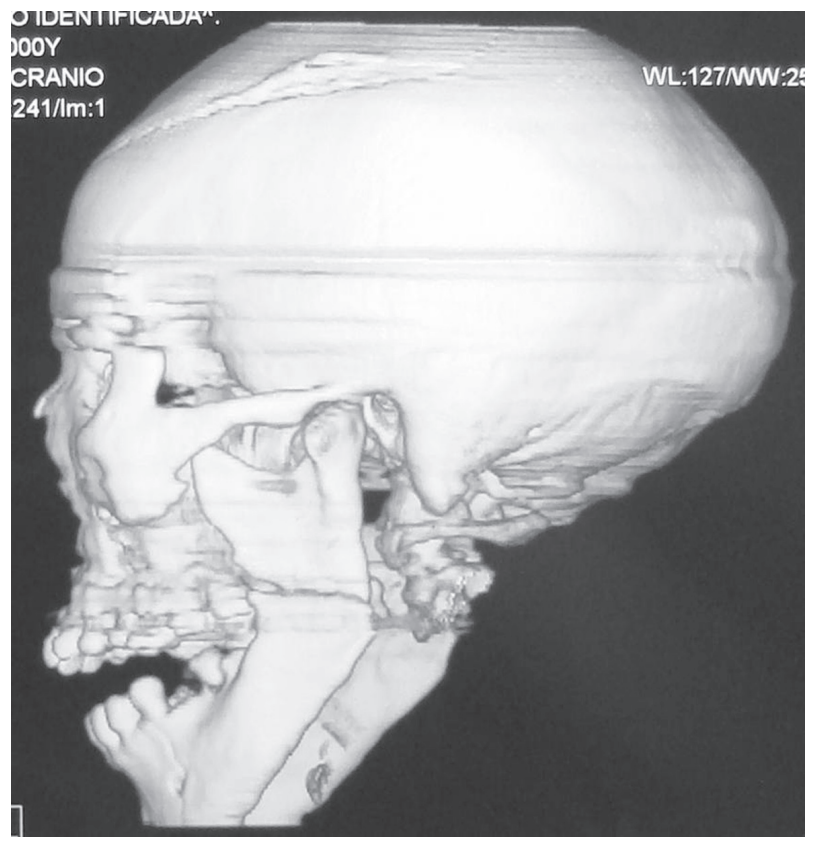

Figure 1. 3D CT reconstruction revealing a fracture in the left mandibular ramus.
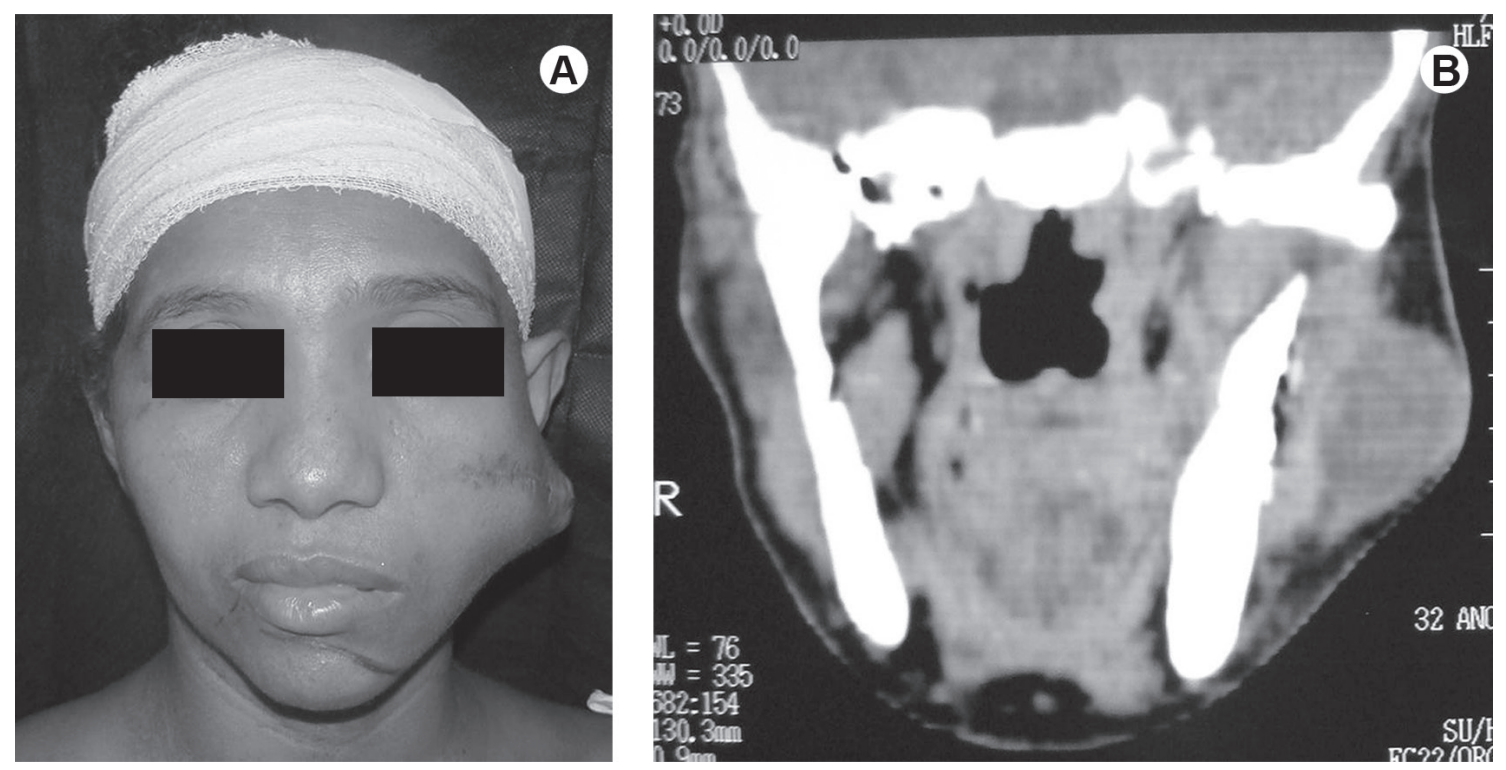

Figure 2. A = Nodule on the left parotid region. $\mathrm{B}=\mathrm{CT}$ scan (soft-tissue window) showing an isointense and well-demarcated nodule on the left preauricular region. 
or signs of recurrence (Fig. 4).

\section{DISCUSSION}

Facial trauma can cause significant esthetic and functional disfunction as well as impairment of important anatomical structures. Lacerations in the parotid-masseter region can cause damage to the facial nerve, transverse artery of the face and parotid gland (5). Involvement of this gland in episodes of facial trauma is uncommon and often associated to fractures of the facial skeleton. However, injury to the parotid duct and/ or parenchyma occasionally causes the accumulation of salivary secretion in the adjacent soft tissue, in a phenomenon known as sialocele (1).

To characterize the clinical features of sialocele, the case described herein was joined to additional 72 cases retrieved from the literature (Table 1). The age of 13 out of 72 patients could be retrieved from the literature, leading to a mean age of 45.9 years. Similarly to a previous report, fourth decade represented the greatest cluster of patients $(6,7)$. Considering gender, $65.28 \%$ of the cases affected women, leading to a female-to-male ratio of 1.88:1. In fact, a similar gender distribution yielding female predilection has been previously reported elsewhere $(8,9)$. While the causes of the condition may be varied, there is currently a greater tendency toward an association tumor excision (48 cases, 66.6\%).

The patient of the case reported herein progressed

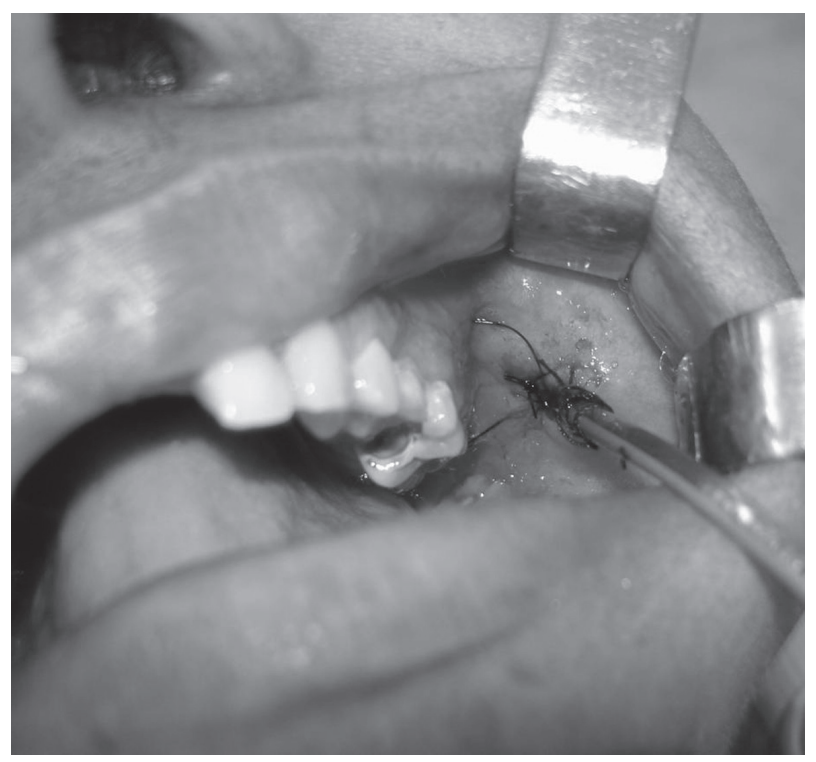

Figure 3. Intraoral view of the drainage area. with an increased volume in the left parotid-masseter region on the tenth day following the trauma, with no signs or symptoms of infection. Puncture and aspiration associated to CT was of considerable value to the definitive diagnosis. The imaging exam clearly revealed a unilocular cyst with a homogeneous, hypodense content in relation to the adjacent tissues, which rested on the superficial lobe of the left parotid gland. The presence of salivary secretion in the lesion confirmed the clinical suspicion.

Diagnosis of rapid growing masses of the parotid region include acute inflammatory diseases, such as sialolitiasis, retrograde parotitis and viral parotitis, as well as sialocele. Notwithstanding, only sialocele is related to a previous trauma, which leads to prompt clinical recognition. To better characterize lesions of the salivary duct mage examination such as CT scan, ultrasound and magnetic resonance imaging are widely used. Also, sialography is an important complementary exam, which indicates the extension of the injury and confirms the site of communication between the duct and affected facial region. Nevertheless, the development of new diagnostic tools, such as sialographic magnetic resonance and endoscopic techniques has considerably optimized the diagnosis of gland conditions (6).

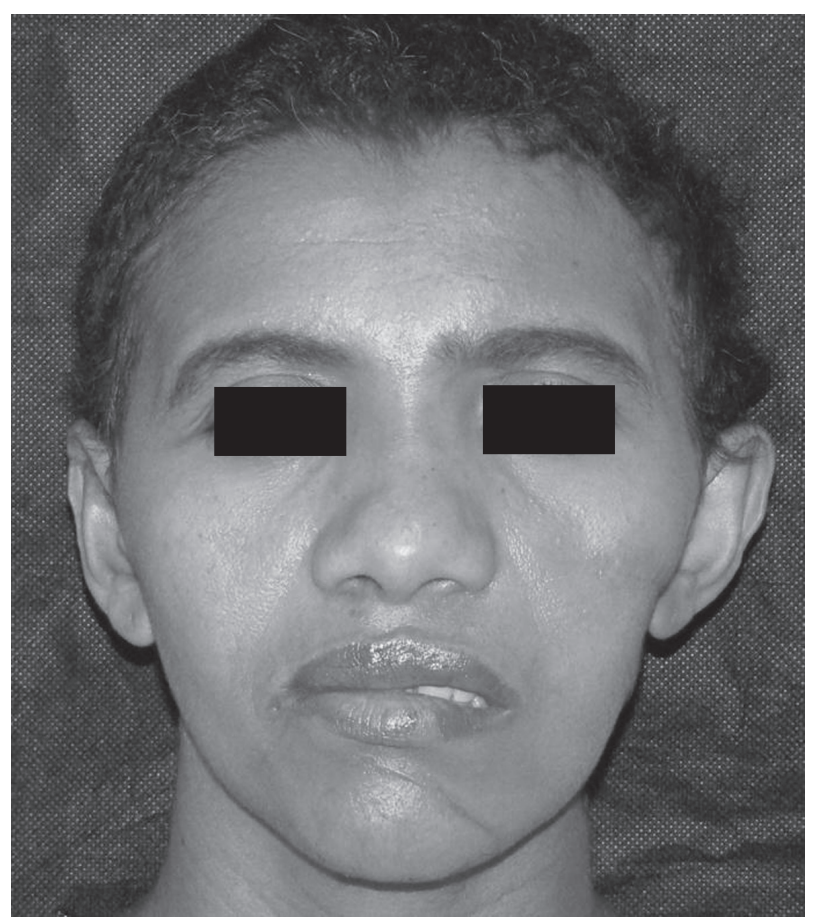

Figure 4. Complete clinical resolution after cannulation of parotid duct. 
Treatment of sialocele can be somewhat distinctive. Table 1 shows a predominant use of conservative treatment (53 cases, 73.6\%) over more invasive methods (19 cases, 26.4\%). The choice of treatment must rely on factors such as time elapsed since the injury, gland site affected, trauma mechanism and experience of the surgeon. Ideally, the patient is treated as soon as possible, but when there is considerable loss of gland structure or when the patient has multiple injuries, there may be an indication for delayed intervention (7). Successive percutaneous aspirations, compress applications and use of antisialogogue medication are among the more conservative approaches normally used as the initial treatment (3). Moreover, the use of parenteral nutrition as a measure for reducing autonomous salivary stimulation has been reported as adjuvant therapy. Botulinum toxin type has been described as safe, effective, non-invasive treatment for sialorrhea, salivary fistula, Frey's syndrome and sialocele, considerably reducing the need for successive aspirations (8). Thus, conservative approaches are effective in the treatment of parotid injury (9). However, some cases may not respond positively to such treatment and more invasive complementary procedures may be needed, as in the case described here.

Invasive or aggressive procedures include local installation of drains for the cannulation of a new salivary duct pathway, low-level radiotherapy for the induction of glandular fibrosis to stop saliva production, partial or complete parotidectomy and tympanic neurectomy to extinguish the secreting parasympathetic enervation of the parotid (10). Cannulation of a new parotid duct using vacuum suction drains has proven to be a quite effective, low-cost method with a low rate of complications and was the option chosen for the case reported here following the failure of the initial approach. Nevertheless, it is associated with a relative discomfort and an elevated infection risk. The patient had the device installed for 15 days without complications and no sign of recurrence was noted after 28 months of follow up.

In summary, sialocele of the parotid gland is a characteristic that frequently originates from penetrating facial trauma. An accurate physical exam and imaging exams are essential to the correct diagnosis. The use of more conservative treatment modalities is indicated as the initial option, but may give way to more invasive

Table 1. Clinical data of parotid sialocele reported in English-language data literature from 1999 to date.

\begin{tabular}{|c|c|c|c|c|c|}
\hline Autor/Year & $\begin{array}{l}\text { Patient } \\
\text { number }\end{array}$ & Gender & Age or mean age (m.a.) & Etiology & Treatment \\
\hline Gahir et al., 2009 & 1 & M & 51 & Tumor excision & Conservative \\
\hline Witt, 2009 & 39 & $16 \mathrm{M} ; 23 \mathrm{~F}$ & 51 (m.a.) & Tumor excision & Conservative \\
\hline Nahlieli et al., 2008 & 14 & $\mathrm{~F}$ & 58 (m.a.) & Cosmetic surgery & Surgery \\
\hline Jayasuriya et al., 2008 & 1 & M & 64 & Trauma & Conservative \\
\hline Abramova et al., 2008 & 1 & $\mathrm{~F}$ & 79 & Tumor excision & Conservative \\
\hline Pereira et al., 2007 & 1 & $\mathrm{~F}$ & 10 & Trauma & Surgery \\
\hline Hashemi et al., 2006 & 1 & $\mathrm{~F}$ & 17 & Trauma & Surgery \\
\hline Winkler et al., 2006 & 2 & $\mathrm{~F}$ & 57 (m.a.) & Cosmetic surgery & Surgery/Conserv. \\
\hline Lapid et al., 2004 & 1 & $\mathrm{~F}$ & 60 & Cosmetic surgery & Conservative \\
\hline Capaccio et al., 2004 & 1 & M & 41 & Tumor excision & Conservative \\
\hline Chow ad Kwok, 2003 & 1 & M & 52 & Tumor excision & Conservative \\
\hline Barrom et al., 2001 & 1 & $\mathrm{~F}$ & 47 & Cosmetic surgery & Conservative \\
\hline Smith et al., 2001 & 1 & M & 14 & Trauma & Conservative \\
\hline Lai et al., 2001 & 1 & M & 54 & Tumor excision & Conservative \\
\hline Vargas et al., 2000 & 4 & $2 \mathrm{M} ; 2 \mathrm{~F}$ & 37 (m.a. - men); 60 (m.a.; women) & Tumor excision & Conservative \\
\hline Canosa and Cohen, 1999 & 2 & $1 \mathrm{M} ; 1 \mathrm{~F}$ & 40 - men and 68 - women & Trauma & Surgery \\
\hline
\end{tabular}


procedures if necessary. Cannulation of the parotid duct with active vacuum suction drain seems to be an adequate treatment option with significant clinical results and great tolerability.

\section{RESUMO}

Lesões na região parotídea e massetérica podem causar danos importantes secundariamente à injúrias de estruturas anatômicas nobres. A sialocele é observada como um aumento de volume facial associado a ruptura do ducto parotídeo devido a trauma. O objetivo deste artigo é relatar um caso de sialocele parotídea gigante traumática, por arma branca, em uma paciente de 40 anos de idade. Em virtude do insucesso de medidas conservadoras de tratamento, uma intervenção cirúrgica por meio de instalação de um dreno à vácuo foi proposta. Sob anestesia local, uma pequena incisão foi realizada adjacente ao ducto da papila parotídea, seguida de divulsão do plano muscular e drenagem de quantidade significativa de saliva. Um dreno à vácuo foi instalado e mantido por 15 dias objetivando formar um novo ducto salivar. Esta técnica se mostrou segura, efetiva e de baixo custo, proporcionando a completa resolução do caso; não sendo observada recidiva em acompanhamento de 28 meses.

\section{ACKNOWLEDGEMENTS}

The authors acknowledge financial support from The National Council for Scientific and Technological Development (CNPq; Process \#480291/2009-8).

\section{REFERENCES}

1. Akinbami BO. Traumatic diseases of parotid gland and sequalae. Review of literature and case reports. Niger J Clin Pract 2009:12:212-215.

2. Monfared A, Ortiz J, Roller C. Distal parotid duct pseudocyst as a result of blunt facial trauma. Ear Nose Throat J 2009;88:15-17.

3. Upton DC, McNamar JP, Connor NP, Harari PM, Harting GK. Parotidectomy: ten-year review of 237 cases at a single institution. Otolaryngol Head Neck Surg 2007;136:788-792.

4. Gahir D, Niamat J, Avery C, Smith A. Novel method of managing persistent parotid sialocele. Int J Oral Maxillofac Surg 2009;38:580-581.

5. Witt RL. The incidence and management of sialocele after parotidectomy. Otolaryngol Head Neck Surg 2009;140:871-874.

6. Barron RD, Margulis A, Icekson M, Zeltser R, Eldad A, Nahlieli
O. Iatrogenic parotid sialocele following rhytidectomy: diagnosis and treatment. Plast Reconstr Surg 2001;108:1782-1784.

7. Capaccio P, Cuccarini V, Beniccio V, Minorati D, Spadari F, Ottaviani F. Treatment of iatrogenic submandibular sialocele with botulinum toxin: case report. Br J Oral Maxillofac Surg 2007;45:415-417.

8. Pereira KD, Smith SL, Mitchell RB. Parotid sialocele in a 10-yearold girl. Ear Nose Throat J 2007;86:27-28.

9. Abramova L, Mann M, Hessler J, Sengelmann RD. Iatrogenic parotid sialocele after excision of malignant melanoma of the cheek. Dermatol Surg 2008;34:1584-1588.

10. Nahlieli O, Abramson A, Shacham R, Puterman MB, Baruchin AM. Endoscopic treatment of salivary gland injuries due to facial rejuvenation procedures. Laryngoscope 2008;118:763-767.

Received December 15, 2010

Accepted September 29, 2011 